\title{
Canadians Look to the North
}

\section{from our Special Correspondent recently in Canada}

"THE first thing to remember is that the north of Canada is the greatest desert in the world." Dr R. F. Legget of the NRC Building Research Division might have added that it is also the coldest, most uncomfortable, least accessible and most underpopulated area in the world-none of these descriptions is far from the mark. Over vast areas the winter ice gives way only to muskeg bog and plagues of blackfly during the short summer; farther north, the ground never thaws. But despite its rigours, Canadians are now making determined efforts to develop the tremendous resources of the north, which almost certainly include large oilfields.

Because of its small population and a wealth of mineral and oil resources farther south, Canada has been slow to exploit the north. The Arctic explorer Vilhjalmur Stefansson, who came from Manitoba, once remarked ruefully that a book he had written predicting the discovery of rich resources in the north had sold only a few hundred copies in Canada, but 40,000 copies in Russia. Two thirds of Canada's population huddle within a hundred miles of the United States border; to the north of them, it is another 2,750 miles to Cape Columbia, Canada's most northerly point. All major lines of communication run from east to west, one reason for a Federal Government plan to spend $\$ 100$ million over ten years to open up great areas of the Yukon Territory. Although ordinary roads are prohibitively expensive, it will be possible to spin the money out by building simple "winter roads" across the ice with a bulldozer and scraper. Using this technique, serviceable roads can be built for as little as $\$ 300$ a mile.

The best known resources of the north are minerals. Silver, gold, asbestos, uranium, copper and zinc have all been discovered. At Pine Point on the Great Slave Lake, processed lead and zinc ores are being produced at the rate of $\$ 100$ million a year, and another large ore body containing zinc and lead has been found near the Ross River. Asbestos is in production in the Yukon, uranium in northern Saskatchewan, and the search for new sources of uranium has been intensified by the Department of Energy, Mines and Resources. In Newfoundland Labrador, a vast iron ore field has been opened up in the past ten years since the building of the Quebec North Shore and Labrador Railway. The ore body at the two mines operated by the Iron Ore Company of Canada at Schefferville and Labrador City is thought to amount to 2,300 million tons.

So far, the most exciting discoveries of oil have been made in Alaska, but nobody doubts that there are substantial reserves in the Canadian north. In the past few years exploration has intensified, and the Federal Government has itself taken a hand by buying a 45 per cent share in a company called Pan-Arctic Oil. The Government, along with the twenty corporations which also have shares in Pan-Arctic, has been prospecting in the Arctic islands, concentrating on Melville Island and Queen Elizabeth Island. If oil is found, Pan-Arctic is hoping that it will be possible to get it out in very large tankers, but this will depend

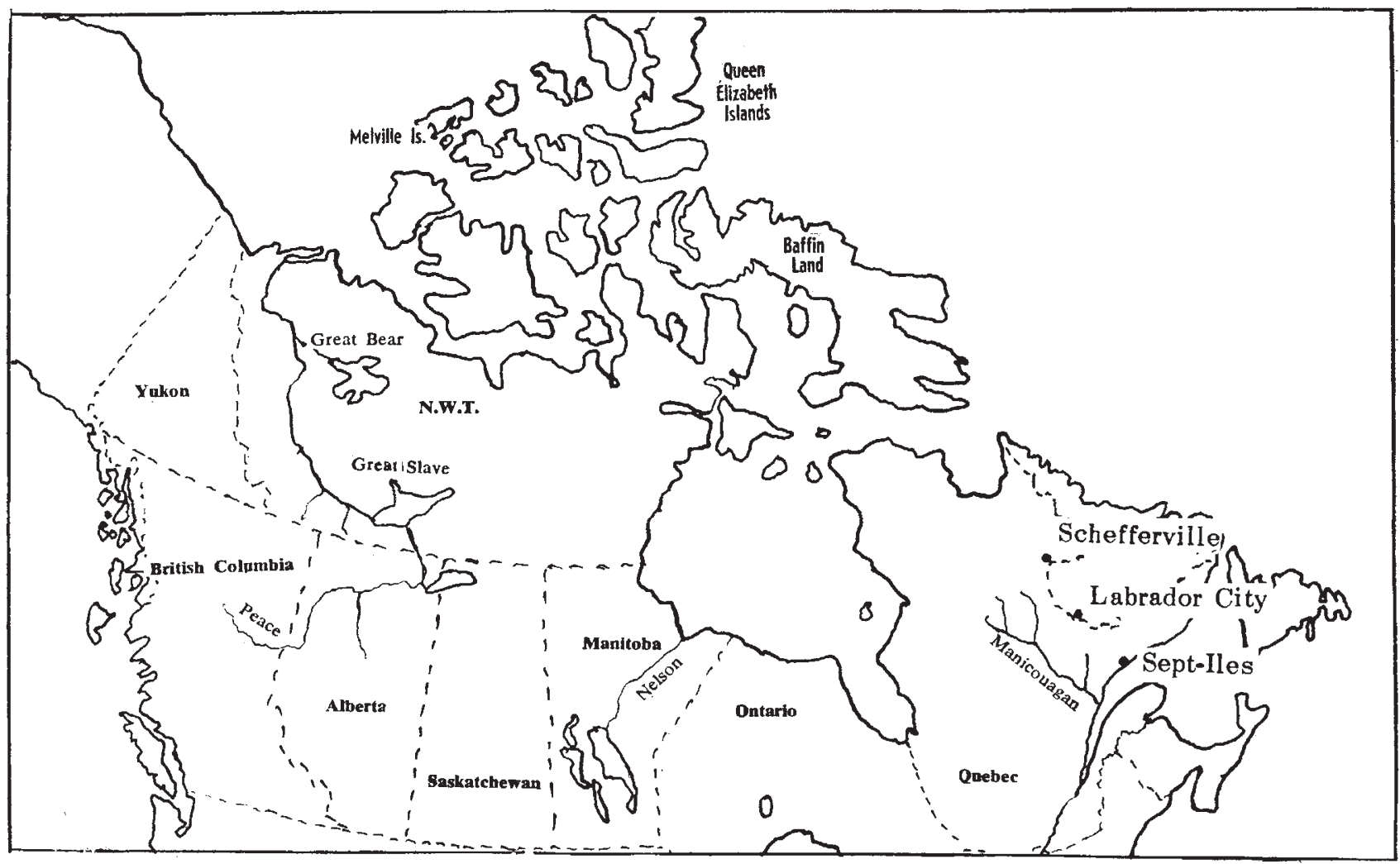


on whether it proves possible to extend the shipping season in the Arctic. Much hope is being placed in a new type of icebreaking bow which can be attached to conventional ships. Called the Alexbow, the bow is shaped rather like a snowplough. Instead of riding up on the ice and crushing it by weight, the Alexbow lifts the ice upwards and to the side. This has two advantages: first, it means that the ice-breaker does not have to overcome the buoyancy of the ice, and secondly, the broken ice, instead of floating in the cleared passage, is pushed on to the ice at the side, leaving the passage clear. This makes it less likely to freeze up again.

Early tests with the Alexbow have been encouraging, and the Department of Energy, Mines and Resources hopes that a 200,000 ton tanker fitted with the Alexbow, stronger steel plates and slightly more powerful engines would transform the economics of oil exploration in the Arctic. The prospects of getting oil out by pipeline are daunting ; apart from the great distances involved, there is always the problem of building a pipe across permafrost. Nobody yet knows whether this could be done.

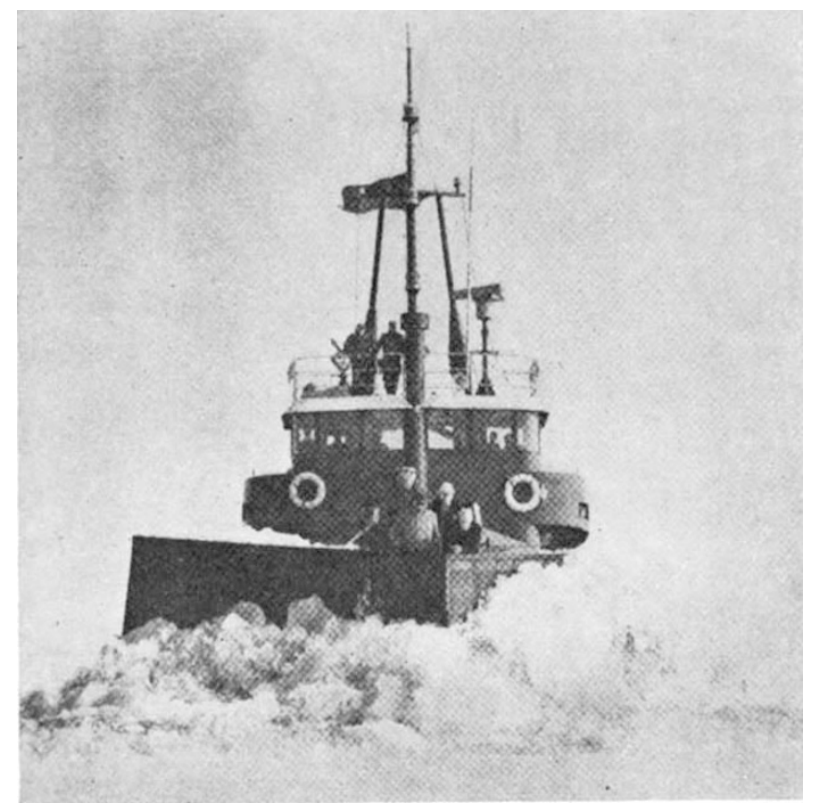

Testing the Alexbow on Lake Ontario.

Quite clearly, communications of one sort or another hold the key to the future development of the north. Until now, telecommunications between the north and the main population centres have been limited and unreliable. The Federal Government is now launched on an imaginative plan to put a communications satellite into geostationary orbit over the Equator, from which it will be possible to provide telephone and television services for small communities. A satellite in a geostationary orbit over the equator between $80^{\circ} \mathrm{W}$ and $120^{\circ} \mathrm{W}$ would be visible as far north as the $78^{\circ}$ latitude; if the satellite were parked in orbit at roughly the same longitude as Winnipeg, it would be able to cover almost the whole of Canada. A satellite like this would offer such enormous advantages that the Federal Government has decided to go ahead, and published a White Paper approving the

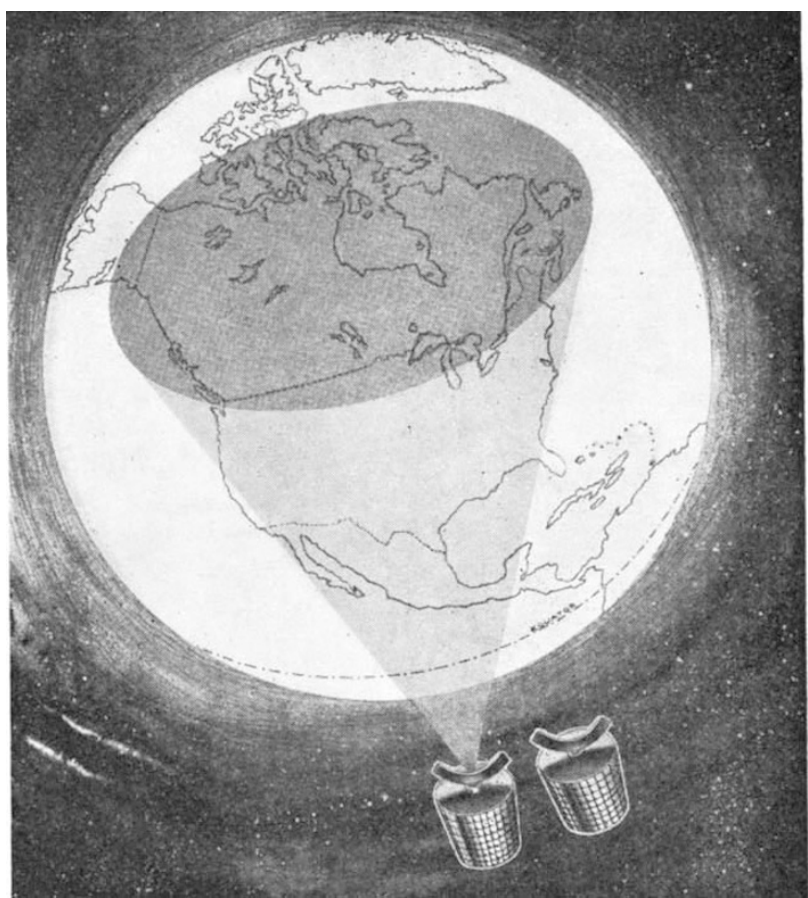

plan in March this year. Two consortia are bidding for the contract to supply the satellite and ground stations; RCA Victor of Montreal in partnership with TRW and Spar Aerospace Products, and Northern Electric in partnership with Hughes Corporation and Canadair. The satellite would weigh about $500 \mathrm{lb}$, about the same as the ISIS A satellite already designed in Canada (and awaiting launch in December), and the typical ground station might be a $30 \mathrm{ft}$ dish offering only a limited amount of movement. The entire budget for the satellite, ground stations and launch is calculated at $\$ 100$ million, although only incurable optimists believe that this figure will not be exceeded.

The greatest problem that remains is launching the satellite. Although Canada has the technical ability to design and build a suitable launcher, most people recognize that it would be foolishness to do so. In effect, this means that Canada is likely to buy a launch from the United States, although there still remains a glimmer of hope that ELDO may yet come up with the answer. A deputation of Canadian Government scientists, headed by Dr J. R. Whitehead of the Science Secretariat, is at present touring Europe, and it is likely that the possibility of a European launcher will figure in talks with European governments.

The north is also being developed as a source of hydro-electric power, both for its own development and for the rest of Canada. The mining operations in Labrador City take their power from the Churchill Falls power station in Labrador, which when fully developed will produce 5,400 megawatts of electricity. In Quebec, the Manicougan River project is almost as vast, and its most important dam, Manic 5, was opened only a few weeks ago by the late Premier Daniel Johnson. In the seventies, the Manicougan project will be generating 4,500 MW. The Nelson River in northern Manitoba is also under development, and it offers the prospect of up to 5,000 MW when fully exploited. 